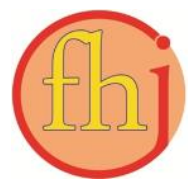

Faletehan Health Journal, 8 (3) (2021) 223-230

www. journal.Ippm-stikesfa.ac.id/ojs/index.php/FHJ

ISSN 2088-673X | e-ISSN 2597-8667

\title{
Analisis Bahaya pada Pengrajin Anyaman Bambu
}

\author{
Isyeu Sriagustini ${ }^{1 *}$, Teni Supriyani ${ }^{1}$ \\ ${ }^{1}$ Program Studi Kesehatan Masyarakat, STIKes Respati, Tasikmalaya \\ *Correspondence Author: isyeutnt@gmail.com
}

\begin{abstract}
Abstrak
Anyaman bambu tidak ada habisnya untuk dibuat berbagai kerajinan tangan dengan nilai guna dan seni yang tinggi. Namun dibalik itu, terdapat proses kerja yang panjang dan kemungkinan potensi bahaya sehingga perlindungan pekerja dibutuhkan. Tujuan penelitian ini adalah mengidentifikasi potensi bahaya lingkungan kerja pada setiap tahap pembuatan kerajinan anyaman bambu. Metode penelitian yang digunakan adalah deskriptif observasional. Subjek penelitian ini adalah pengrajin anyaman bambu dan objek penelitiannya adalah seluruh tahapan kegiatan pembuatan kerajinan anyaman bambu. Hasil penelitian menunjukkan empat kegiatan utama pembuatan kerajinan anyaman bambu, yaitu tahap pembuatan bahan anyaman, tahap penyiapan bahan tambahan anyaman, pembuatan produk anyaman, dan finishing. Dari masing-masing tahap kegiatan pembuatan anyaman bambu, empat potensi bahaya teridentifikasi yakni: bahaya fisik berupa cuaca kerja dan kebisingan; bahaya kimia berupa debu, asap dan bahan kimia yang diaplikasikan; bahaya ergonomi dari cara dan posisi kerja yang tidak ergonomis; dan bahaya mekanik dari bahan dan peralatan yang digunakan. Peneliti menyimpulkan bahwa pada setiap tahap kegiatan pembuatan anyaman bambu terdapat potensi bahaya lingkungan kerja yang perlu diperhatikan oleh pengrajin maupun pemilik usaha. Data hasil identifikasi ini dapat dijadikan sebagai data dasar upaya pengendalian bahaya lingkungan kerja.
\end{abstract}

Kata Kunci: Analisis Bahaya, Anyaman Bambu, Bahaya Lingkungan Kerja

\section{Hazard Analysis on Bamboo Weaving Craftsmen}

\begin{abstract}
Woven bamboo is endless and can be made into various handicrafts with high use and artistic value. But behind that, there is a long work process and possible potential hazards so that worker protection is needed. The purpose of this study was to identify the potential hazards of the work environment at each stage of making bamboo woven crafts. The research method used was descriptive observational. The research subject was bamboo weaving craftsmen and the object was all stages of the activities of making bamboo woven crafts. The results showed four main activities of making bamboo woven crafts, namely the stage of making woven materials, the stage of preparing additional woven materials, making woven products, and finishing. From each stage, four potential hazards were identified, namely: physical hazards in the form of work weather and noise; chemical hazards such as dust, smoke and applied chemicals; ergonomic hazards from non-ergonomic methods and work positions; and mechanical hazards from the materials and equipment used. The researchers concluded that at each stage of the activity of bamboo woven making there are potential hazards of the work environment that need to be considered by craftsmen and business owners. This data of identification results can be used as a database of work environment hazard control efforts.

Keywords: Bamboo Woven, Hazard Analysis, Work Environment Hazard
\end{abstract}




\section{Pendahuluan}

Usaha sektor formal maupun sektor informal harus melaksanakan dan mendapatkan pelayanan upaya kesehatan kerja seperti yang diamanatkan dalam Undang-undang nomor 36 tahun 2009 tentang kesehatan. Upaya kesehatan kerja yang dimaksud ditujukan untuk melindungi pekerja agar hidup sehat dan terbebas dari gangguan kesehatan serta pengaruh buruk yang diakibatkan oleh pekerjaan (Republik Indonesia, 2009).

Perhatian mengenai upaya kesehatan dan keselamatan kerja pada sektor informal sampai saat masih belum optimal bila dibandingkan dengan sektor formal. Pekerjaan pada sektor informal biasanya memiliki kondisi dan keadaan kerja tidak layak, tingkat pendapatan rendah, pekerjaan yang lebih sulit dan berisiko tinggi, tingkat keamanan serta perlindungan terhadap tenaga kerjanya pun rendah (Diana, 2019). Oleh sebab itu pekerja pada kelompok ini merupakan kelompok kerja yang tergolong pada underserved working population dan biasanya belum mendapatkan pelayanan kesehatan kerja seperti yang diharapkan (Munib, 2019). Dari sekian banyaknya jumlah tenaga kerja sektor informal di Indonesia, baru sekitar 1\% saja yang telah dilindungi oleh pembiayaan kesehatan. Pada kenyataanya permasalahan yang dihadapi tenaga kerja sektor informal selain tidak mempunyai jaminan kesehatan, tidak terdaftar secara resmi, juga tidak ada kompensasi akibat kecelakaan kerja maupun penyakit akibat kerja. Selain itu mereka sangat rentan terhadap kecelakaan kerja dan penyakit akibat kerja, karena kesadaran dan pengetahuan akan berbagai potensi bahaya dari pekerjaan, kondisi, bahan dan peralatan di tempat kerja sangat minim (Ramdan, 2012).

Semua jenis pekerjaan dan tempat kerja, baik pada sektor formal maupun sektor informal memiliki potensi bahaya yang ditimbulkan oleh semua aspek yang ada di lingkungan kerja dan memiliki risiko gangguan terhadap kesehatan dan keselamatan pekerja. Pada usaha sektor informal pembuatan dodol kentang misalnya dapat teridentifikasi tiga jenis bahaya yaitu, bahaya fisik, bahaya kimia, dan bahaya ergonomi dan ditemukan sebanyak 37 risiko diantaranya, 13 risiko $(35,1 \%)$ dikelompokkan dalam kategori risiko rendah, 18 risiko $(48,7 \%)$ termasuk kategori risiko sedang, dan 6 risiko $(16,2 \%)$ termasuk kategori risiko tinggi (Adelia, 2018). Berdasarkan hal tersebut bukan tidak mungkin pada usaha sektor informal lainnya pun akan ditemui potensi bahaya dan risiko kesehatan kerja.

Usaha informal ini banyak ragam dan jenisnya. Salah satunya adalah kerajinan anyaman bambu yang merupakan potensi unggulan industri di Kabupaten Tasikmalaya selain bordir, pandan, mendong, dan golok. Kecamatan Leuwisari dikenal sebagai Sentra home industry usaha kerajinan anyaman bambu yang berkualitas di Kabupaten Tasikmalaya (Redaksi, 2018).

Kondisi perlindungan kesehatan kerja pada usaha kerajinan anyaman bambu ini tidak berbeda dengan usaha sektor informal lainnya. Sebenarnya pemerintah telah mengupayakan perlindungan kesehatan kerja melalui program Pos Upaya Kesehatan Kerja, yang sampai pada tahun 2017 telah berdiri sebanyak 410 pos UKK di seluruh Indonesia (Kementrian Kesehatan Indonesia, 2017). Pos Upaya Kesehatan kerja merupakan sebuah wadah berbasis masyarakat untuk pekerja pada sektor informal guna mendapatkan pelayanan kesehatan kerja. Pelayanan ini dimaksudkan untuk upaya pencegakan penyimpangan kesehatan yang disebabkan oleh kondisi pekerjaan dan sebagai perlindungan pekerjaan dari risiko akibat faktor yang merugikan kesehatan pekerja. Oleh sebab itu dengan berjalannya Pos UKK di setiap tempat yang ada usaha pada sektor informal dapat menjadi salah satu cara bagaimana melindungi dan memberikan hak yang sama atas pelayanan kesehatan kerja untuk pekerja pada sektor informal (Kementrian Kesehatan RI, 2015).

Selain itu pemerintah pun mengoptimalkan program kesehatan kerja di puskesmas-puskesmas. Untuk memulai suatu program upaya kesehatan kerja khususnya pada usaha kerajinan anyaman bambu dapat diawali dengan mengenali potensi bahaya pada setiap tahap kegiatan pembuatan kerajinan anyaman bambu, sehingga dapat digunakan sebagai acuan dalam mengurangi tingkat risiko kesehatan maupun kecelakaan kerja dan lebih lanjut dapat menjadi patokan dalam menyusun program pengendalian. Identifikasi bahaya merupakan sebuah proses untuk mengetahui adanya suatu bahaya dan menentukan karakteristiknya. Identifikasi bahaya dapat membantu pengurus perusahaan mengenali dan memahami bahaya di tempat kerjanya sehingga dapat menilai dan memprioritaskan upaya menghilangkan bahaya atau mengurangi risiko 
Faletehan Health Journal, 8 (3) (2021) 223-230

www. journal.Ippm-stikesfa.ac.id/ojs/index.php/FHJ

ISSN 2088-673X | 2597-8667

keselamatan dan kesehatan kerja, terlaksananya upaya keselamatan dan kesehatan kerja di tempat kerja salah satunya adalah bagaimana proses identifikasi dijalankan dengan baik, karena kegiatan identifikasi bahaya ini akan menentukan program pengendalian yang sesuai dengan potensi bahaya yang teridentifikasi (BSI, 2007; Masjuli et al., 2019).

Tujuan Penelitian ini adalah melakukan identifikasi potensi bahaya lingkungan kerja pada setiap tahapan kegiatan pembuatan kerajinan anyaman bambu.

\section{Metodologi Penelitian}

Jenis Penelitian yang digunakan adalah penelitian deskriptif observasional. Penelitian ini dilakukan di Industri Kecil Menengah Serumpun Bambu Kecamatan Leuwisari Kabupaten Tasikmalaya pada bulan Februari 2020. Subjek dalam penelitian ini adalah semua pengrajin yang melakukan aktivitas tahapan pembuatan kerajinan anyaman bambu yang berjumlah lima orang. Sedangkan objek dalam penelitian ini adalah setiap tahapan kegiatan pembuatan produk kerajinan anyaman bambu yang semuanya ada dua tahap kegiatan utama yaitu: tahap pembuatan bahan anyaman (ebeg), tahap pembuatan produk kerajinan anyaman bambu.

Metode Identifikasi potensi bahaya yang digunakan adalah Job Hazard Analysis (JHA) dengan langkah menentukan tahap kegiatan pekerjaan yang akan dianalisis, mendeskripsikan pekerjaan yang dianalisis, dan identifikasi potensi bahaya pada setiap tahap kerja dan pengendalian bahaya yang dilakukan (OSHA, 2002). Data dikumpulkan dengan cara observasi dan wawancara dengan menggunakan lembar observasi dan panduan wawancara $5 \mathrm{~W}+1 \mathrm{H}$. Observasi dilakukan untuk mengumpulkan data tahapan kegiatan pembuatan anyaman bambu dan bagaimana pekerjaan tersebut dilakukan oleh pekerja, serta kondisi lingkungannya. Sedangkan wawancara dilakukan kepada pekerja untuk memperjelas data hasil observasi. Data dianalisis secara deskriptif dan ditampilkan dalam bentuk narasi dan tabel.

\section{Hasil dan Pembahasan}

Berdasarkan pengamatan di lapangan, potensi bahaya yang ada pada setiap tahap kegiatan pembuatan kerajinan anyaman bambu dapat dilihat pada gambar 1 sebagai berikut:
Gambar 1: Potensi Bahaya pada Setiap Tahap Pembuatan Kerajinan Anyaman Bambu

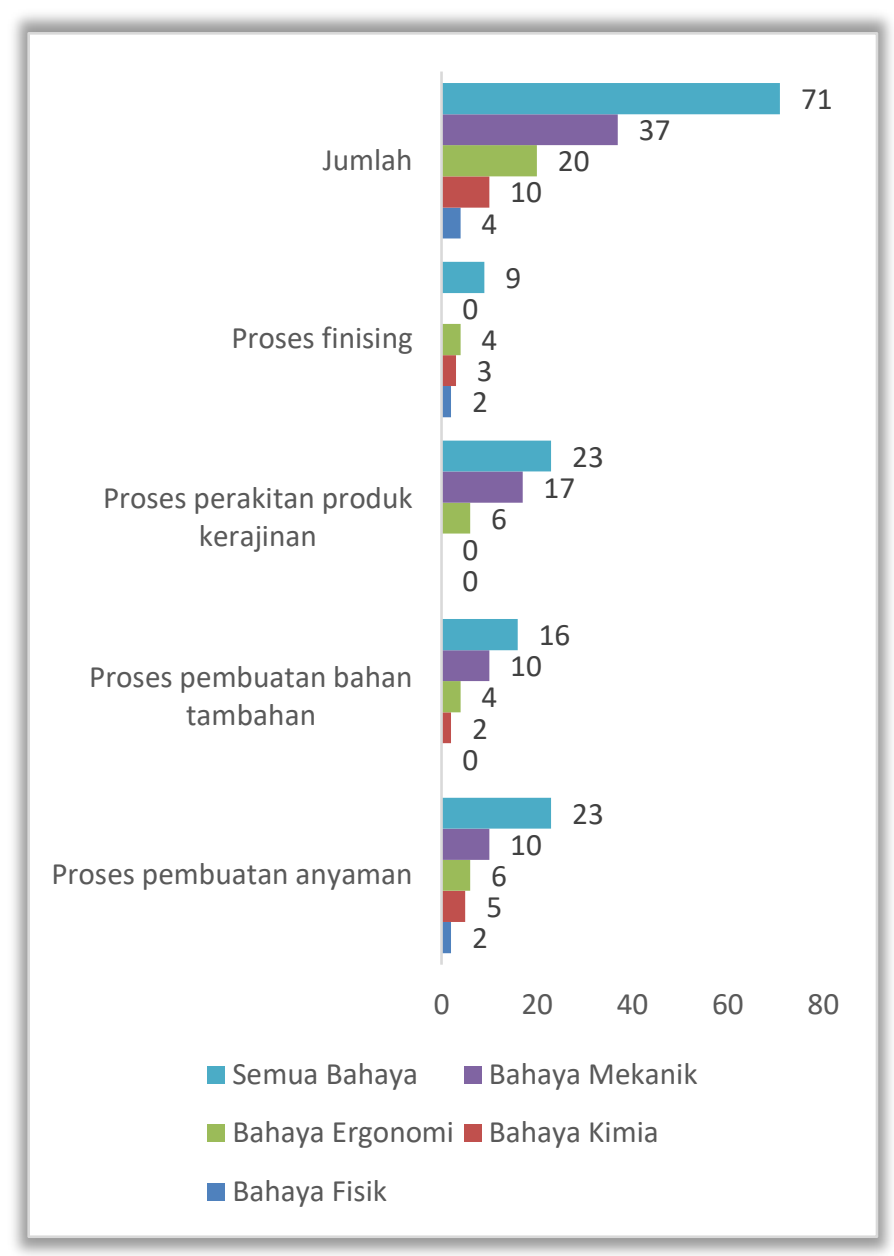

Berdasarkan gambar di atas dapat diketahui bahwa jenis potensi bahaya pada masing- masing tahap adalah: potensi bahaya pada tahap proses pembuatan anyaman teridentifikasi sebanyak 23 potensi bahaya dengan potensi bahaya yang dominan adalah bahaya mekanik, bahaya ergonomi dan bahaya kimia. Pada tahap pembuatan produk kerajinan anyaman bambu dapat diketahui bahwa, potensi bahaya pada tahap penyiapan bahan tambahan teridentifikasi sebanyak 16 potensi bahaya dengan rincian 2 potensi bahaya merupakan jenis bahaya kimia, 4 potensi bahaya merupakan jenis bahaya ergonomi dan 10 potensi bahaya merupakan jenis bahaya mekanik; Pada tahap perakitan produk kerajinan teridentifikasi sebanyak 23 potensi bahaya dengan rincian 6 potensi bahaya merupakan jenis bahaya ergonomi dan 17 potensi bahaya merupakan jenis bahaya mekanik; dan pada proses finishing teridentifikasi 
sebanyak 9 potensi bahaya dengan rincian 2 potensi bahaya merupakan jenis bahaya fisik, 3 potensi bahaya merupakan jenis bahaya kimia, dan 4 potensi bahaya merupakan jenis bahaya ergonomi.

\section{Potensi Bahaya Mekanik}

Potensi bahaya yang paling banyak adalah bahaya mekanik yaitu faktor yang berasal dari benda-benda bergerak, benda-benda tajam, benda yang berukuran lebih besar dan berat yang dapat menimbulkan risiko pada pekerja seperti tersayat, tertusuk, terjepit, terhimpit, terpotong, tertabrak dan sebagainya (Kementerian Ketenagakerjaan RI, 2018). Potensi bahaya mekanik lebih mengarah pada bahaya yang berasal dari peralatan dan bahan yang digunakan. Penelitian Fani (2013), menyatakan bahwa pada tahap memotong kayu pada industri mebel terdapat bahaya mekanik yang teridentifikasi seperti: terkena bilah gergaji, terkena tendangan balik dari serpihan kayu dan terkena tekstur kayu yang tajam. Penelitian Astuti (2017), menjelaskan potensi bahaya mekanik yang teridentifikasi pada pengrajin bambu berupa tangan terkena bambu dan alat kerja, kaki terkena sisa-sisa bambu yang berada di lantai, terpeleset dan jatuh, serbuk bambu dan kayu akan terhirup dan mengganggu pernapasan, menghirup zat berbahaya yang terkandung dalam pernis (getah damar dan bensin) dan menyebabkan gangguan pernafasan jangka panjang dan terjadi kebakaran jika bensin terkena percikan api.

Sama halnya dengan penelitian yang sudah dilakukan oleh Fani maupun Astuti, potensi bahaya mekanik pada tahap pembuatan kerajinan anyaman bambu terdiri dari: bahaya yang pertama berasal dari penggunaan alat gergaji, bedog, gunting, penggunaan obeng, paku, palu dan pisau raut. Pada tahap pemotongan digunakan gergaji untuk memotong bambu dan bedog untuk membagi bambu gelondongan menjadi belahan bambu. Risiko penggunaan alat tersebut adalah pekerja memiliki kemungkinan untuk terpotong, sehingga menyebabkan luka pada anggota tubuh terutama tangan. Bahaya mekanik yang kedua berasal dari peralatan atau bahan panas. Pada tahap pewarnaan digunakan peralatan yang panas akibat proses pemasakan air menggunakan api. Api menyebabkan peralatan panas begitu pula dengan airnya. Jika tidak hati-hati pengrajin memiliki risiko terkena peralatan panas maupun percikan air sehingga menyebabkan luka bakar pada tubuh yang terkena. Bahaya mekanik yang ketiga berasal dari bahan bambunya itu sendiri, baik dari bambu gelondongan, bilah bambu, helai, jarugjug, wengku maupun sisa rautan bambu. Pada prinsipnya bahan bambu memiliki sifat yang tajam dan jika tidak hati-hati pengrajin kemungkinan akan mengalami luka sayat akibat kontak dengan bahan bambu.

Upaya yang dilakukan oleh pengrajin untuk menghindari risiko bahaya mekanik ini belum dilakukan, apalagi terkait dengan bahaya yang berasal dari penggunaan peralatan dan bahan bambu. Pengrajin menggunakan bahan kain atau "cempal" saat harus kontak dengan peralatan panas. Penelitian yang dilakukan oleh Wati (2020), diketahui bahwa pada home industry konveksi teridentifikasi pula bahaya mekanik dari penggunaan peralatan berupa gunting maupun jarum. Upaya yang dilakukan untuk mengendalikan bahaya mekanik tersebut adalah penggunaan sarung tangan, agar dapat menghindari tangan dari risiko kecelakaan yang bersumber dari peralatan tajam. Pengendalian tersebut dapat diaplikasikan pada pengrajin anyaman bambu saat menggunakan peralatan tajam, peralatan atau bahan panas juga untuk menghindari kontak dengan bahan bambu itu sendiri. Sarung tangan yang digunakan dapat disesuaikan dengan kenyaman dari pengrajin saat melakukan pekerjaannya.

\section{Potensi Bahaya Ergonomi}

Potensi bahaya terbanyak selanjutnya adalah bahaya ergonomi yaitu faktor yang dapat mempengaruhi aktivitas tenaga kerja, disebabkan oleh ketidaksesuaian antara fasilitas kerja yang meliputi cara kerja, posisi kerja, alat kerja, dan beban angkat terhadap tenaga kerja (Kementerian Ketenagakerjaan RI, 2018). Sama halnya dengan bahaya mekanik, bahaya ergonomi dapat teridentifikasi hampir di semua proses kegiatan pembuatan kerajinan anyaman bambu, baik pada tahap pembuatan bahan anyaman (ebeg), pada tahap pembuatan bahan tambahan produk, maupun pada tahap perakitan produk. Sumber potensi bahaya ergonomi berasal dari terlalu lama dalam posisi yang janggal atau tidak alamiah seperti duduk di lantai dan membungkuk baik itu punggung dan leher, duduk dengan jongkok, dan menggunakan tangan secara berulang dalam waktu cukup lama.

Permasalahan ergonomi pada umumnya dapat teridentifikasi pada usaha sektor informal. Seperti 
Faletehan Health Journal, 8 (3) (2021) 223-230

www. journal.Ippm-stikesfa.ac.id/ojs/index.php/FHJ

pada pengrajin emping dan keripik didapatkan posisi pekerja saat bekerja tidak ergonomis, dimana pekerja harus membungkuk terus saat bekerja, selama minimal 4 jam tanpa istirahat atau relaksasi, kecuali ke kamar kecil. Bahaya ergonomi yang sama juga teridentifikasi pada pada proses pembuatan sepatu yaitu pekerja yang duduk terus menerus di kursi pendek, sikap kerja yang tidak ergonomis atau postur janggal dari para pekerjanya (Khasanah, 2019; Sutanti, 2017).

Adapun potensi bahaya ergonomi pada tahapan pembuatan kerajinan bambu tergambar salah satunya pada proses pemotongan dari bambu gelondongan menjadi potongan bambu sesuai ukuran, dilakukan pekerja sambil jongkok diantara bambu gelondongan lainnya. Proses pembuatan helai bambu (hua), dilakukan dengan cara duduk di lantai dengan kedua kaki selonjor ke depan ataupun duduk bersila. Hal yang sama tergambar pada proses menganyam dengan duduk di lantai, biasanya satu kaki diangkat tertelungkup menginjak anyaman dan satunya lagi diletakan yang juga tertekuk. Kepala menunduk yang disandarkan ke kaki yang terangkat menginjak bahan anyaman. Sementara tangan memasukan helai bambu (hua) secara repetitif sampai menjadi sebuah anyaman bambu (ebeg). Semua proses dalam kegiatan penyiapan bahan tambahan produk dilakukan dengan cara duduk di lantai. Selain itu untuk menyesuaikan pekerjaan dengan daya pandang maka kadang pengrajin membungkukkan kepala mengikuti rendahnya bahan yang dikerjakan. Posisi tersebut biasanya susah sekali diubah, dan pekerja pun merasa lebih nyaman seperti itu.

Posisi kerja yang tidak alamiah seperti postur tubuh yang statis pada punggung dan leher juga pada kaki dalam keseluruhan tahap kegiatan ini cukup memakan waktu lama, sehingga akan terjadi tekanan pada bagian tubuh tertentu karena otot berkontraksi terus menerus, dan pekerja akan mengalami keluhan muskuloskeletal pada leher dan punggungnya. Posisi duduk yang tidak ergonomis memungkinkan terjadinya tekanan pada tulang punggung, sehingga dapat menimbulkan nyeri, dan jika dibiarkan lama akan low back pain (Suma'mur, 2009; Tarwaka, 2010).

Keluhan akibat posisi kerja yang tidak alamiah tersebut tersebut dirasakan oleh pengrajin ukiran kayu, pengrajin batik tulis dan pekerja lainnya. Posisi kerja yang paling sering dilakukan oleh pengrajin ukiran kayu adalah membungkuk dan sedikit menunduk pada saat pengukiran maupun pengamplasan. Akibatnya pengrajin mengeluhkan rasa sakit dan pegal di sekitar tangan dan punggung, sakit pada lututnya. Pengrajin batik tulis melakukan pekerjaan sambil duduk dengan kepala tertunduk dan tangan terangkat sedemikian untuk menopang dan melukiskan batik. Dari aktivitasnya itu pengrajin mengeluhkan musculoskeletal tingkat sedang, tinggi dan sangat tinggi (Saputro et al., 2018; Wiratma \& LMISH, 2015). Hal serupa akan dimungkinkan terjadi pada pengrajin anyaman bambu karena potensi bahaya ergonomi yang ada pada setiap tahapan pembuatan kerajinan anyaman bambu.

Upaya yang dapat dilakukan untuk mengendalikan bahaya ergonomi di tempat kerja adalah dengan menerapkan prinsip ergonomi selama bekerja. Salah satu prinsip yang dapat digunakan adalah bekerja dalam posisi netral. Posisi netral dicapai ketika otot berada pada posisi istirahat dan persendian sejajar secara alami. (Moore et al., 2011). Posisi kerja pengrajin saat melakukan pembuatan kerajinan bambu teridentifikasi banyak posisi yang tidak alamiah, oleh sebab itu posisi kerja selama pembuatan kerjainan anyaman bambu dapat diupayakan berada pada posisi alamiah tubuh. Selain itu upaya yang dapat dilakukan adalah istirahat yang cukup dan peregangan tubuh. Istirahat selama proses kerja dapat dilakukan sekurang-kurangnya setengah jam setelah bekerja selama 4 jam secara terus menerus (Republik Indonesia, 2003). Selama jam istriahat pengrajin bisa meregangkan tubuh, sehingga otot-otot yang kaku selama bekerja dapat Kembali normal.

\section{Potensi bahaya Kimia}

Bahaya kimia adalah faktor yang dapat mempengaruhi aktivitas tenaga kerja yang bersifat kimiawi disebabkan oleh penggunaan bahan kimia dan turunannya di tempat kerja yang dapat menyebabkan penyakit pada tenaga kerja, meliputi kontaminan kimia di udara berupa gas, uap dan partikulat (Kementerian Ketenagakerjaan RI, 2018). Potensi bahaya bahan kimia yang dapat teridentifikasi dari seluruh rangkaian proses kerja anyaman bambu yang pertama adalah adanya debu. Debu adalah zat kimia padat, yang disebabkan oleh kekuatan- kekuatan alami atau mekanis seperti pengolahan, penghancuran, pelembutan, pengepakan yang cepat, peledakan, dan lain-lain daribenda, baik organic maupun anorganik 
(Suma'mur, 2009). Kegiatan pemotongan bambu dengan menggunakan gergaji dihasilkan butiran kecil bambu yang menyertai proses pemotongan. Tidak sedikit debu ini berterbangan saat proses penggergajian dan ada kemungkinan terhirup atau tersebar ke seluruh bagian tubuh si pekerja. Begitu pula pada kegiatan pembuatan helai bambu (hua) dan membuat wengku. Ada bagian pada proses kerja ini kegiatan menghaluskan bahan terlebih dahulu sebelum bahan tersebut diproses selanjutnya. Proses penghalusan baik menggunakan pisau dengan cara diraut atau cara lainnya akan menghasilkan butiran debu dari bahan bambu yang terbuang.

Debu di tempat kerja jika tidak ditangani akan menimbulkan keluhan atau gangguan fungsi pernafasan. Debu yang ada di bagian sanding pada industri mebel diketahui melebihi nilai ambang batas. Pekerja yang terpapar menunjukkan gangguan fungsi paru, dan bahkan pekerja yang terpapar kadar debu di atas NAB berisiko 2,7 kali lebih besar dibandingkan dengan pekerja yang terpapar kadar debu di bawah NAB (Putri et al., 2017). Adapun debu yang dihasilkan pada pembuatan kerajinan bambu tidak begitu banyak tetapi perlu diwaspadai dan diukur karena banyak juga debu yang berterbangan. Hal yang perlu diperhatikan bahwa debu bambu biasanya menyebabkan alergi kulit atau gatal atau dalam bahasa Sunda disebut debu bambu mengandung "merang" yang dapat membuat gatal ketika kena pada kulit.

Potensi Bahaya kimia lainnya bersumber dari pewarna sintetis, lem kayu, dan pernis. Pada saat pewarnaan, pekerja membubuhkan pewarna sintetis yaitu napthol atau pewarna lain yang tergolong cat basis yang dapat dicampur-campur sesuai keinginan. Penggunaan dosis warna tergantung dari warna yang diinginkannya, jika warna muda biasanya digunakan setengah dosis dan jika warna gelap biasanya digunakan satu dosis. Setiap bungkus naptol dapat digunakan untuk ribuan helai bambu (hua). Lem fox atau lem kayu adalah bahan kimia yang digunakan pada proses pembuatan produk kerajinan bambu. Lem fox atau lem kayu diaplikasikan untuk memperkuat anyaman bambu pada produk akhir sebelum pemlituran. Pernis digunakan untuk tujuan produk kerajinan yang dihasilkan lebih bagus dan tahan lama. Jenis pernis yang digunakan bisa dipilih sesuai dengan tujuan, ada berbagai cat kayu yang ditujukan khusus untuk pernis. pada pengrajin anyaman bambu ini digunakan campuran arpus dan bensin untuk tujuan pernis.

Risiko kesehatan dari penggunaan bahan pewarna ini adalah terhirup, tertelan dan kontak dengan kulit dan mata. Jika terhirup dapat menyebabkan iritasi saluran nafas disertai gejala batuk dan nafas pendek. Jika tertelan dalam dosis tinggi bisa mengakibatkan rasa sakit pada perut, muntah, mual, berkeringat, penurunan tekanan darah, anemia, konvulsi, kematian. Paparan terhadap kulit yang berulang kali menyebabkan dermatitis kulit. Selain itu dapat menyebabkan iritasi mata kemerahan, nyeri dan kerusakan pada kornea.

Pengendalian risiko bahan kimia yang sudah dilakukan oleh pengrajin selama melakukan proses kerja adalah penggunaan penutup hidung meskipun bukan masker tetapi hanya kain kerudung yang dililitkan di sekitar hidung guna mengurangi terhirup debu. Upaya yang dapat dilakukan untuk mengendalikan risiko bahaya kimia pada pembuatan kerajinan anyaman bambu adalah penggunaan alat pelindung yang sesuai, misalnya masker untuk melindungi terhirupnya debu selama bekerja. Seperti penelitian yang dilakukan oleh Indrawati et al. (2015), bahwa Pekerja di pabrik pakan ikan yang tidak menggunakan APD berisiko 26,4 kali mengalami gangguan fungsi paru dibandingkan dengan pekerja yang menggunakan APD. Rekomendasi penggunaan APD ini dikarenakan debu hasil sampingan dari proses kerja tidak dapat dieliminasi maupun disubtitusi bahan. Zat pewarna dapat dihilangkan manakala konsumen tidak menginginkan produk dengan warna tertentu, namun menganti zat pewarna dengan pewarna alami dapat dipertimbangkan untuk mengurangi risiko akibat penggunaan zat pewarna, lem dan juga pernis.

\section{Potensi Bahaya Fisik}

Bahaya fisik adalah faktor di tempat kerja yang dapat mempengaruhi aktivitas tenaga kerja yang bersifat fisika. Hal tersebut disebabkan oleh penggunaan mesin, peralatan, bahan dan kondisi lingkungan di sekitar tempat kerja yang dapat menyebabkan gangguan dan penyakit akibat kerja pada tenaga kerja yang meliputi iklim kerja, kebisingan, getaran, radiasi gelombang mikro, radiasi ultra ungu (Ultraviolet), radiasi medan magnet statis, tekanan udara, dan pencahayaan (Suma'mur, 2009). Bahaya fisik yang dapat teridentifikasi dari proses kerja anyaman bambu 
Faletehan Health Journal, 8 (3) (2021) 223-230

www. journal.Ippm-stikesfa.ac.id/ojs/index.php/FHJ

ISSN 2088-673X | 2597-8667

adalah pada tahap kegiatan pemotongan, pembuatan helai bambu (hua), Pewarnaan, dan Finishing. Pada kegiatan pemotongan, potensi bahaya lingkungan kerja yang muncul adalah kebisingan. Kebisingan bersumber dari aktivitas penggunaan alat gergaji yang dipakai untuk memotong bambu gelondongan menjadi bambu sesuai ukuran yang dibutuhkan. Intensitas kebisingan yang ada kemungkinan tidak melebihi NAB karena ketika sumber kebisingan tersebut ada, secara subjektif dapat dinilai dengan komunikasi pekerja masih dapat didengar jelas. Lama paparan kebisingan pun tidak terus menerus, hanya selama proses pemotongan itu berlangsung sampai dengan habisnya bahan bambu yang dipotong. Pemotongan tidak dilakukan setiap hari kerja, namun tergantung dari habisnya bahan, yaitu sekitar tiga hari sekali dilakukan pemotongan.

Potensi bahaya fisik lainnya di dapat dari kegiatan pembuatan helai bambu (hua). Potensi bahaya yang teridentifikasi pada proses ini adalah panas yang bersumber dari cahaya terik matahari saat penjemuran helai bambu (hua), dan api hawu saat kegiatan pewarnaan. Helai bambu (hua) akan memiliki kualitas yang baik apabila kadar air yang ada dikurangi. Proses pengurangan kadar air dilakukan dengan cara penjemuran di terik mata hari. Pada saat itu pekerja diharuskan membawa satu persatu helai bambu (hua) ke pelataran rumah yang kemungkinan tersinari matahari untuk menjemurnya. Hasil helai bambu (hua) dengan kualitas yang baik di dapat jika helai bambu (hua) dibolak balik selama proses penjemur, sehingga keringnya merata. Oleh sebab itu pekerja akan mendapat paparan sinar matahari selama proses kegiatan ini.

Proses pewarnaan membutuhkan air mendidih supaya warna tercampur dan melekat pada helai bambu (hua). Oleh sebab itu pekerja akan terpapar lingkungan kerja yang panas yang bersumber dari proses pembakaran bahan bakar dari "hawu". Proses pembakaran tersebut akan memberikan hawa panas ke seluruh ruangan, apalagi ditunjang dengan ruangan yang kurang penghawaan, maka hal tersebut akan menyebabkan pekerja kepanasan dan berkeringat.

Potensi bahaya fisik yang berupa panas di lingkungan kerja pun teridentifikasi pada kegiatan finishing. Sama halnya dengan penjemuran helai bambu (hua), produk anyaman yang telah dibuat dan melewati proses pengeleman akan dilanjutkan kepada proses penjemuran untuk menghasilkan kualitas pengeleman yang kuat. Proses penjemuran dilakukan di teras rumah dengan sumber cahaya matahari. Oleh sebab itu pekerja akan terpapar panas cahaya matahari.

Upaya yang dapat dilakukan untuk mengendalikan risiko kebisingan pada pembuatan kerajinan anyaman bambu adalah penggunaan sumbat telinga apabila kebisingan sudah di atas NAB. Penelitian Mayasari (2017), menyebutkan bahwa penggunaan penyumbat telinga atau penutup telinga bisa menghalangi suara hingga frekuensi tertentu. Penyumbat telinga dan penutup telinga dapat memberi pemakainya penurunan dengan intensitas $10 \mathrm{~dB}$ sampai $40 \mathrm{~dB}$. Pemilihan APD tersebut setelah mempertimbangan pendekatan eliminasi dan subtitusi sebelumnya. Adapun pengendalian risiko heatstrees adalah rekayasa tempat kerja dengan menempatkan sumber panas dalam ruangan yang cukup terbuka dan ventilasi yang bagus sehingga dapat mengurangi keluhan kegerahan dan kelelahan saat bekerja.

\section{Simpulan}

Terdapat empat potensi bahaya yang teridentifikasi dari seluruh tahapan kegiatan pembuatan kerajinan anyaman bambu yakni: bahaya mekanik dari bahan dan peralatan yang digunakan, bahaya ergonomi dari cara dan posisi kerja yang tidak ergonomis, bahaya kimia dari bahan kimia yang diaplikasikan, dan bahaya fisik berupa cuaca kerja (panas) dan kebisingan. Potensi bahaya lingkungan kerja yang paling banyak teridentifikasi pada setiap tahapan kegiatan pembuatan kerajinan anyaman bambu adalah bahaya mekanik $(46,58 \%)$.

\section{Referensi}

Adelia, N. (2018). Analisa Manajemen Risiko pada Pekerja Pembuat Dodol Kentang di Desa Lubuk Nagodang, Kecamatan Siulak, Kabupaten Kerinci, Provinsi Jambi. Universitas Sumatra Utara.

Astuti, Ma. (2017). Analisis Budaya Kerja UKM Industri Bambu di Cebongan Sleman Jogjakarta. Prosiding SINTI Dan SATELIT, F91-97.

BSI. (2007). OSHAS 18000 Sistem manajemen keselamatan dan kesehatan kerja. In British Standards Institute (BSI).

Diana, F. N. (2019). Pekerja Informal Dan Kemiskinan Di Kabupaten Bekasi. 
Ayobekasi.Net.

http://m.ayobekasi.net/read/2019/05/20/2805/ pekerja-informal-dan-kemiskinan-dikabupaten-bekasi.

Fani, H. (2013). Penilaian Risiko Keselamatan Kerja dari Bahaya Mekanik hingga Pekerja Pembuatan Furnitur KAyu di Industri Informal "Indah JAti Furniture." Skripsi. Jakarta: Fakultas Kesehatan Masyarakat Universitas Indonesia.

Indrawati, I., Zulkarnaini, Z., \& Suyanto, S. (2015). Analisis Pengaruh Kepadatan Debu dan Penggunaan APD Pekerja Pabrik Pakan Ikan Terhadap Gangguan Fungsi Paru Pada Pekerja Pabrik Pakan Ikan di Kecamatan XIII Koto Kampar. Dinamika Lingkungan Indonesia, 2(2), 129-132.

Kementerian Ketenagakerjaan RI. (2018). Peraturan Menteri Ketenagakerjaan Republik Indonesia Nomor 5 Tahun 2018 Tentang Keselamatan Dan Kesehatan Kerja Lingkungan Kerja.

Kementrian Kesehatan Indonesia. (2017). Laporan Tahunan Direktorat Kesehatan Kerja dan Olahraga.

Peraturan Menteri Kesehatan Republik Indonesia Nomor 100 Tahun 2015 Tentang Pos Upaya Kesehatan Kerja Terintegrasi, Kemnetrian Kesehatan Republik Indonesia (2015).

Khasanah, U. (2019). Analisis Risiko Kesehatan Kerja Pada Pekerja Pembuatan Sepatu Di Home Industry Sepatu Kulit Manding Yogyakarta. Universitas Ahmad Dahlan.

Masjuli, Awan Taufani, \& Amri Abu Kasim. (2019). Sistem Manajemen Keselamatan dan Kesehatan Kerja Berbasis SNI ISO 45001:2018.

Mayasari, D. (2017). Pencegahan Noise Induced Hearing Loss pada Pekerja Akibat Kebisingan. Jurnal Agromedicine, 4(2), 354360.

Moore, S. M., Torma-Krajewski, J., \& Steiner, L. J. (2011). Practical demonstrations of ergonomic principles.

Munib, A. (2019). Industri Furnitur Berbasis Padat Karya dan Orientasi Ekspor - Sektor Riil. Www.Neraca.Co.Id.

http://www.neraca.co.id/article/114118/sekto r-riil-industri-furnitur-berbasis-padat-karyadan-orientasi-ekspor

OSHA. (2002). Job Hazard Analysis. U.S. Departement Labour.
Putri, R. K., Darundiati, Y. H., \& Dewanti, N. A. Y. (2017). Hubungan Paparan Debu Kayu Terhirup Dengan Gangguan Fungsi Paru Pada Pekerja Di Industri Mebel Cv. Citra Jepara Furniture Kabupaten Semarang. Jurnal Kesehatan Masyarakat (e-Journal), 5(5), 832-837.

Ramdan, I. M. (2012). Memperbaiki Kondisi Kesehatan Dan Keselamatan Kerja Sektor Informal Melalui Program Corporate Social Responsibility. Jurnal Manajemen Pelayanan Kesehatan, 15, 2-6.

Redaksi. (2018). Industri kerajinan Kabupaten Tasikmalaya Merambah Pasar Mancanegara. Fokus JAbar. https://fokusjabar.com/beritapriangan/industri-kerajinan-kabupatentasikmalaya-merambah-pasar-mancanagarah10091.html

Republik Indonesia. (2003). Undang Undang Nomor 13 tahun 2003 tentang Ketenagakerjaan.

Republik Indonesia. (2009). Undang-Udang Nomor 36 Tahun 2009 Tentang Kesehatan. Republik Indonesia.

Saputro, C. B., Mulyono, M., \& Puspikawati, S. I. (2018). Hubungan Karakteristik Individu dan Sikap Kerja terhadap Keluhan Muskuloskeletal pada Pengrajin Batik Tulis. Journal of Public Health Research and Community Health Development, 2(1), 1-10.

Suma'mur, P. K. (2009). Higiene perusahaan dan kesehatan kerja (HIPERKES). Sagung Seto.

Sutanti, Y. S. (2017). Kesehatan Dan Keselamatan Kerja Pada Pengrajin Emping Dan Keripik Di Kota Cilegon Banten. Prosiding Seminar Dan Workshop PEI, 209-229.

Tarwaka. (2010). Ergonomi Industri Dasar-dasar pengetahuan ergonomi dan aplikasi di tempat kerja. Harapan press.

Wati, I. S. (2020). Potensi Bahaya pada Home Industry Konveksi. HIGEIA (Journal of Public Health Research and Development), 4(3), 384-397.

Wiratma, I. K. A., \& LMISH, A. (2015). Gambaran Keluhan Muskuloskeletal pada perajin ukiran kayu di Kecamatan Manggis Kabupaten Karangasem. E-Jurnal Medika Udayana, 4(10), 1-12. 